\title{
FLOW INJECTION ANALYSIS SYSTEM COUPLED WITH ICP-EOS FOR DETERMINATION OF SOME METALLIC ELEMENTS IN DRINKING WATER
}

\author{
Cristina Dinu*, Gabriela Vasile, Liliana Cruceru, Jana Petre \\ National Research and Development Institute for Industrial Ecology ECOIND, 90-92 Road Panduri, Bucharest, \\ e-mail: ecoind@incdecoind.ro
}

\begin{abstract}
The European Drinking Water Directive (98/83/EC), transposed in Romanian Legislation as Low $458 / 2002$, amended by Low 311/2004, imposes the limit of concentration for metallic elements in water intended for human consumption. The toxic metals arsenic and selenium are among these elements and the limit value is 10 $\mu \mathrm{g} / \mathrm{L}$. In the paper there are presented the working conditions for determination of As and Se from drinking water using modern techniques based on the flow injection-hydride generation with the inductively coupled plasma atomic emission spectrometry (FIAS-ICP-EOS). The analyses were performed on Optima 5300 DV Perkin Elmer equipment with FIAS 400 Flow Injection System, Perkin Elmer type. For the hydride generation two types of solution were used: $10 \%(\mathrm{v} / \mathrm{v}) \mathrm{HCl}$ as a carrier solution and $0.2 \% \mathrm{NaBH}_{4}$ in $0.05 \% \mathrm{NaOH}$ solution as a reducing agent [1]. The treatment step of the samples and standard solutions consisted in reducing with mixed solutions of KI and ascorbic acid in acidic condition $(\mathrm{HCl})$ for $\mathrm{As}$ and only with $\mathrm{HCl}$ and high temperature for Se $[2,3]$. The paper contains the characteristic parameters of the methods, such as: low detection limit, quantification limit, repeatability, precision, recovery, which were evaluated using Certified Reference Materials for each element.
\end{abstract}

Keywords: drinking water, As, Se, hydride analyses, ICP-EOS.

\section{Introduction}

Nowadays the determination of trace elements in drinking water is a matter of real interest because of the role of water in the human metabolism and the consequences of ingestion for human health. The European Drinking Water Directive (98/83/EC), transposed in Romanian Legislation as Low 458/2002, amended by Low 311/2004, imposes the limits of concentration for metallic elements in water intended for human consumption. The toxic metals arsenic and selenium are among these elements and the limit value is $10 \mu \mathrm{g} / \mathrm{L}$.

Arsenic may be found in water which has flowed through arsenic-rich rocks. Severe health effects have been observed in populations drinking arsenic-rich water over long periods, in countries worldwide. Chronic arsenic poisoning, as occurs after long-term exposure through drinking water is very different to acute poisoning. Immediate symptoms of an acute poisoning typically include vomiting, oesophageal and abdominal pains, and bloody "rice water" diarrhoea. Chelation therapy may be effective in acute poisoning but should not be used against long-term poisoning. Long-term exposure to arsenic via drinking-water causes cancer of the skin, lungs, urinary bladder, and kidney, as well as other skin changes such as pigmentation changes and thickening (hyperkeratosis). Increased risks of lung and bladder cancer as well as arsenic-associated skin lesions have been observed at drinking-water arsenic concentrations of less than $0.05 \mathrm{mg} / \mathrm{L}$. Absorption of arsenic through the skin is minimal and thus hand-washing, bathing, laundry, etc. with water containing arsenic do not pose human health risk [4].

Selenium is toxic within large amounts, but trace amounts of it are necessary for the cellular function in most, if not all, animals, forming active centres of the enzymes glutathione peroxidase and thioredoxin reductase. Although selenium is an essential trace element, it is toxic if taken in excess. Exceeding the Tolerable Upper Intake Level of 400 micrograms per day can lead to selenosis [5]. Symptoms of selenosis include a garlic odour on the breath, gastrointestinal disorders, hair loss, sloughing of nails, fatigue, irritability and neurological damages. Extreme cases of selenosis can result in cirrhosis of the liver, pulmonary oedema and death [5]. Elemental selenium and most metallic selenides have relatively low toxicities because of their low bioavailability. By contrast, selenates and selenites are very toxic, having an oxidant mode of action similar to that of arsenic trioxide. The chronic toxic dose of selenite for human beings is about 2400 to 3000 micrograms of selenium per day for a long time [6]. Hydrogen selenide is an extremely toxic, corrosive gas. Selenium poisoning of water systems may result whenever new agricultural runoff courses through normally dry undeveloped lands. This process leaches natural soluble selenium compounds (such as selenates) into the water, which may then be concentrated in new "wetlands" as the water evaporates.

Accurate measurement of arsenic in drinking-water at levels relevant to health requires laboratory analysis, using sophisticated and expensive techniques and facilities while trained staff not easily available in many parts of the world. Analytical quality control and external validation remain problematic. Field test kits can detect high levels of these elements but are typically unreliable at lower concentrations of concern for human health.

Usually, these elements can be detected using UV-VIS spectrometry, AAS [15], atomic absorption spectrometry coupled with FIAS technique [7], GF-AAS [8,9], ICP-EOS [10,11], ICP-MS [12,13], HG-ICP-MS [14] TXRF[15], LC- 
MS[16], HPLC-ICP-MS [17,18]. In the paper there are presented the working conditions for determination of As and Se from drinking water using modern techniques based on the flow injection-hydride generation with the inductively coupled plasma atomic emission spectrometry (FIAS-ICP-EOS). The methods applied with this modern technique have low detection limits (As $-0.21 \div 0.59 \mu \mathrm{g} / \mathrm{L}, \mathrm{Se}-0.21 \mu \mathrm{g} / \mathrm{L}$ ), situated under the limit values imposed by legislation.

\section{Experimental Section}

Apparatus: Flow Injection Hydride Generation System FIAS 400 with Inductively Coupled Plasma Optical Emission Spectrometer ICP-EOS type Optima 5300 DV Perkin Elmer, Analytical Balance Kern ABT 220-50M, Bandelin Sonorex Water Bath (only heating function).

Reagents: Merck solution for calibration (1000 mg As/L; $1000 \mathrm{mg} \mathrm{Se/L,} \mathrm{ICP} \mathrm{standards),} 100 \mathrm{mg} / \mathrm{L}$ multielement Perkin Elmer SRM, hydrochloric acid ( 37\%, Merck quality), potassium iodide (99,995\% purity, Merck quality), L-ascorbic acid ( $>99 \%$, Sigma-Aldrich quality); sodium borohydride ( $>96 \%$, Merck quality), sodium hydroxide (pellets, Gr for analysis, Merck quality), argon 99,996\% purity, nitrogen 99,999\% purity (Linde-Gas quality), ultrapure water.

Procedure: The water samples (drinking water, groundwater, surface water) and standard solutions for As and Se determinations should be pre-reduced prior the analysis (table 1). For each set of standards a blank sample using the same procedure was prepared. For the hydride vapour generation two types of solution were used: $10 \%(\mathrm{v} / \mathrm{v}) \mathrm{HCl}$ as a carrier solution and $0.2 \% \mathrm{NaBH}_{4}(\mathrm{w} / \mathrm{v})$ in $0.05 \% \mathrm{NaOH}(\mathrm{w} / \mathrm{v})$ solution as a reducing agent, which should be freshly prepared.

Table 1

Pre-treatment step for the As and Se determinations with FIAS-ICP-EOS

\begin{tabular}{|c|c|c|}
\hline Element & Reduction & \multicolumn{1}{c|}{$\begin{array}{c}\text { Pre-treatment procedure for each standard } \\
\text { solution and sample }\end{array}$} \\
\hline $\mathrm{As}$ & $\mathrm{As}^{5+}$ to $\mathrm{As}^{3+}$ & $\begin{array}{l}5 \mathrm{~mL} 5 \%(\mathrm{w} / \mathrm{v}) \text { potassium iodide and } 5 \%(\mathrm{w} / \mathrm{v}) \text { ascorbic acid, } 45 \mathrm{minutes} \\
\text { at room temperature. }\end{array}$ \\
\hline $\mathrm{Se}$ & $\mathrm{Se}^{6+}$ to $\mathrm{Se}^{4+}$ & $2 \mathrm{~mL} \mathrm{HCl} \mathrm{concentrated,} \mathrm{heated} \mathrm{on} \mathrm{a} \mathrm{water} \mathrm{bath} \mathrm{at} 90^{\circ} \mathrm{C}$ for 20 minutes. \\
\hline
\end{tabular}

The operational parameters for the spectrometer, plasma, FIAS and data processing are presented in Table 2.

Parameters for FIAS-ICP-EOS

Table 2

\begin{tabular}{|c|c|c|c|c|c|}
\hline \multicolumn{6}{|c|}{ Spectrometer parameters } \\
\hline \multicolumn{3}{|c|}{ As Wavelengths: $193.696,188.979,197.197 \mathrm{~nm}$} & \multicolumn{2}{|l|}{ Replicates } & 3 times \\
\hline \multirow{2}{*}{\multicolumn{3}{|c|}{ Se Wavelength: $196.026 \mathrm{~nm}$}} & \multicolumn{2}{|l|}{ Purge Gas Flow } & normal \\
\hline & & & \multicolumn{2}{|c|}{ Transient Read Delay } & $0.0 \mathrm{sec}$ \\
\hline \multicolumn{3}{|c|}{ Integration time: $0.05 \mathrm{sec}$} & \multicolumn{2}{|c|}{ Transient Read Time } & $15.0 \mathrm{sec}$ \\
\hline \multicolumn{6}{|c|}{ Plasma parameters } \\
\hline Plasma flow rate & \multicolumn{2}{|c|}{$15 \mathrm{~L} / \mathrm{min}$} & \multicolumn{2}{|l|}{ Power RF } & $1350 \mathrm{~W}$ \\
\hline Auxiliary flow rate & \multicolumn{2}{|c|}{$0.2 \mathrm{~L} / \mathrm{min}$} & Plasma View & \multicolumn{2}{|c|}{ Axial } \\
\hline Nebuliser flow rate & \multicolumn{2}{|c|}{$0.5 \mathrm{~L} / \mathrm{min}$} & View distance & \multicolumn{2}{|c|}{$15.0 \mathrm{~mm}$} \\
\hline \multicolumn{6}{|c|}{ Flow Injection Programme } \\
\hline Step & Time $(\mathrm{s})$ & Pump 1 (U/min) & Pump 2 (U/min) & Valve & Read \\
\hline Prefil & 15 & 80 & 100 & Fill & - \\
\hline 1 & 10 & 80 & 100 & Fill & - \\
\hline 2 & 15 & 80 & 100 & Inject & On \\
\hline
\end{tabular}

\begin{tabular}{|l|l|}
\hline \multicolumn{1}{|c|}{ Spectral Peak Processing } & \multicolumn{2}{c|}{ Time Processing } \\
\hline Peak Algorithm : Peak Height $\quad$ Peak Algorithm : Peak Height \\
\hline Points per peak : 3 points & Smoothing points : 19 points \\
\hline Spectral corrections : None & \\
\hline
\end{tabular}

The hydride technique involves the reaction of acidified aqueous samples with a reducing agent, such as sodium borohydride. This reaction generates a volatile hydride which is transported to a quartz cell by means of an argon carrier gas. In the quartz cell, the hydrides are converted to gaseous metal atoms, which are then transported in plasma by argon gas. Plasma generation of the ICP-EOS spectrometer requires argon gas as fuel. Nitrogen gas is used only for the cooling 
system of the equipment. The purity of all reagents used is critical when determining low levels of hydride elements. Table 1 summarizes preceding treatments for the As and Se determinations with FIAS-ICP-EOS.

ICP-EOS uses specific wavelengths to detect metallic elements; the methods applied with this equipment are perfectly able to measure accurately an analyte in the presence of interferences.

In order to evaluate the performances of the methods some standard solutions for As and Se using Certified Reference Material (1000 mg/L, Certipur ICP Standard, traceable to SRM from NIST) were prepared during the experimental tests. For the recovery test a multielement SRM type Perkin Elmer Quality Control Standard 21 was used, with $100 \mathrm{mg} / \mathrm{L}$ As and Se. To establish the performance parameters of the methods, the tests indicated in Table 3 were performed.

Table 3

Performed tests used for performance parameters of the methods

\begin{tabular}{|c|c|c|c|}
\hline Linearity & LOD and LOQ & $\begin{array}{c}\text { Test for the homogeneity } \\
\text { of the variance }\end{array}$ & $\begin{array}{c}\text { Repeatability precision, } \\
\text { recovery }\end{array}$ \\
\hline $\begin{array}{l}10 \text { standard solutions between } \\
\qquad 2 \mu \mathrm{g} / \mathrm{L} \div 20 \mu \mathrm{g} / \mathrm{L}\end{array}$ & \multirow{2}{*}{\begin{tabular}{|l}
$10 \quad$ independent \\
blank $\quad$ solutions \\
measured each of \\
them once.
\end{tabular}} & $\begin{array}{l}\text { - } 10 \text { independent standard } \\
\text { solutions of } 2 \mu \mathrm{g} / \mathrm{L} \\
\text { concentration; }\end{array}$ & $\begin{array}{l}\text { - } 10 \text { independent standard } \\
\text { solutions of } 15 \quad \mu \mathrm{g} / \mathrm{L} \\
\text { concentration. }\end{array}$ \\
\hline $\begin{array}{l}1 \mathrm{~mL} ; 2 \mathrm{~mL} ; 3 \mathrm{~mL} ; 4 \mathrm{~mL} ; 5 \mathrm{~mL} ; 6 \\
\mathrm{~mL} ; 7 \mathrm{~mL} ; 8 \mathrm{~mL} ; 9 \mathrm{~mL} \text { and } 10 \mathrm{~mL} \\
\text { from } 0.1 \mathrm{mg} / \mathrm{L} \text { to } 50 \mathrm{~mL} \text { with } 10 \% \\
\mathrm{HCl} .\end{array}$ & & $\begin{array}{l}\text { - } 10 \text { independent standard } \\
\text { solutions of } 20 \mu \mathrm{g} / \mathrm{L} \\
\text { concentration. }\end{array}$ & $\begin{array}{l}\text { - } 5 \text { independent standard } \\
\text { solutions of } 5 \mu \mathrm{g} / \mathrm{L}, 15 \mu \mathrm{g} / \mathrm{L} \\
\text { and } 20 \mu \mathrm{g} / \mathrm{L} \text { concentrations } \\
\text { (Perkin Elmer QCS 21). }\end{array}$ \\
\hline
\end{tabular}

The mathematical relations and the admissible range or value for some important parameters, such as: bias, coefficient of variation (relative standard deviation) and recovery are presented in Table 4.

Two aspects are important for Internal Quality Control: the analysis of "control materials", such as CRM or spiked samples, to monitor the trueness (recovery) and replication of analysis to monitor the precision. Both aspects form a part of statistical control, a tool for monitoring the accuracy of an analytical system. Recovery studies were performed to the same matrix type (drinking water) at different levels of analyte concentration [19].

Table 4

Mathematical equations used for evaluation of recovery, precision and bias

\begin{tabular}{|c|c|c|}
\hline Recovery, \% & Bias, \% & Relative standard deviation, \\
\hline $\begin{array}{c}\bar{\eta}(\%)=\frac{\overline{x_{f}}-\overline{x_{b}}}{\overline{x_{a}}} 100, \%, \\
\overline{x_{f}}=\text { mean value of fortified samples, } \mu \mathrm{g} / \mathrm{L} ; \\
\overline{x_{b}}=\text { mean value of unfortified samples, } \mu \mathrm{g} / \mathrm{L} ; \\
{ }_{x_{a}}=\text { concentration of added standard solution, } \mu \mathrm{g} / \mathrm{L} .\end{array}$ & $\begin{array}{c}\text { Bias }=\frac{x_{f}-x_{a}}{x_{a}} \times 100, \% \\
\text { Bias value }<\mathrm{t}(99,9)=2.82 \\
{[21,22]}\end{array}$ & $\begin{array}{c}\mathrm{RSD}=\frac{S_{r}}{\bar{x}} \times 100, \\
\mathrm{~S}_{\mathrm{r}}=\text { standard deviation of } \\
\text { concentrations, } \mu \mathrm{g} / \mathrm{L} ; \\
\bar{x}=\text { mean value of } \\
\text { concentrations, } \mu \mathrm{g} / \mathrm{L} . \\
\text { for } 10 \mu \mathrm{g} / \mathrm{L}, \text { acceptable RSD } \\
\quad \text { values: } \\
\text { Horwitz, } 22.6-33 \% \text {; AOAC } \\
\text { Peer Verified Methods, } 15 \\
-21 \%[20,22]\end{array}$ \\
\hline
\end{tabular}

\section{Results and discussion}

The working range for As and Se determination using FIAS-ICP-EOS is linear between 2 and $20 \mu \mathrm{g} / \mathrm{L}$ for all tested wavelengths. In the tests for the homogeneity of the variance, PG values are lower than Fischer-Snedecor's " $F$ " value. The values of coefficient of variation (As: $1.77 \%$ for $\lambda=193.696 \mathrm{~nm}, 2.77 \%$ for $\lambda=197.197 \mathrm{~nm}$ and $1.39 \%$ for $\lambda=188.979 \mathrm{~nm}$; Se: $\lambda=197.197 \mathrm{~nm}$ ), lower than $3 \%$, situate the test methods as good analytical methods. The detection limits (LOD) and quantification limits (LOQ) allow the detection of As and Se from drinking water samples at the normed level of concentration (Table 5). 
Linearity, LOD and LOQ

\begin{tabular}{|c|c|c|}
\hline \multicolumn{3}{|c|}{ As, $\Lambda=193.696 \mathrm{~nm}$} \\
\hline $\begin{array}{c}y=-138.13+764 \cdot x \\
\text { linear equation }\end{array}$ & $\begin{array}{c}\mathrm{B}=764 \mu \mathrm{g}^{-1} \mathrm{~L} \\
\text { sensitivity, the slope of the calibration } \\
\text { curve }\end{array}$ & $\begin{array}{c}\mathrm{s}^{2}=0.89 \mathrm{E}+08, \\
\mathrm{~s}_{10}^{2}=3.9 \mathrm{E}+08, \mathrm{PG}=\mathrm{s}^{2}{ }_{10} / \mathrm{s}^{2}=4.39< \\
\mathrm{F}_{9,9 ; 0,99}=5.35\end{array}$ \\
\hline $\begin{array}{l}\quad \mathrm{S}_{\mathrm{Y} 1}=149 \mu \mathrm{g} / \mathrm{L} \\
\text { residual standard deviation }\end{array}$ & $\begin{array}{c}\mathrm{S}_{\mathrm{x} 01}=0.19 \mu \mathrm{g} / \mathrm{L} \\
\text { method of standard deviation }\end{array}$ & $\begin{array}{c}\mathrm{V}_{\mathrm{x} 01}=1.77 \% \\
\text { coefficient of variation }\end{array}$ \\
\hline $\begin{array}{c}\mathrm{R}=0.9995 \\
\text { Correlation coefficient, accepted } \\
\text { values } \mathrm{R} \geq 0.997\end{array}$ & \multicolumn{2}{|c|}{$\begin{array}{c}\bar{x}=0.214 \mu \mathrm{g} / \mathrm{L}, \sigma_{\text {blank }}=0.04 \mu \mathrm{g} / \mathrm{L} \\
\mathbf{L O D}=0.33 \mu \mathrm{g} / \mathrm{L}, \mathbf{L O Q}=0.61 \mu \mathrm{g} / \mathrm{L}\end{array}$} \\
\hline \multicolumn{3}{|c|}{ As, $\Lambda=197.197 \mathrm{~nm}$} \\
\hline $\begin{aligned} y= & -100.4+461.17 \cdot x \\
& \text { linear equation }\end{aligned}$ & $\begin{array}{c}\mathrm{b}=461.17 \mu \mathrm{g}^{-1} \mathrm{~L} \\
\text { sensitivity, the slope of the calibration } \\
\text { curve }\end{array}$ & $\begin{array}{c}\mathrm{s}^{2}{ }_{1}=0.55 \mathrm{E}+07, \\
\mathrm{~s}^{2}{ }_{10}=2.72 \mathrm{E}+07, \mathrm{PG}=\mathrm{s}^{2}{ }_{10} / \mathrm{s}^{2}{ }_{1}= \\
4.96<\mathrm{F}_{9,9 ; 0,99}=5.35\end{array}$ \\
\hline $\begin{array}{l}\quad \mathrm{S}_{\mathrm{Y} 1}=140.45 \mu \mathrm{g} / \mathrm{L} \\
\text { residual standard deviation }\end{array}$ & $\begin{array}{c}\mathrm{S}_{\mathrm{x} 01}=0.30 \mu \mathrm{g} / \mathrm{L} \\
\text { method of standard deviation }\end{array}$ & $\begin{array}{c}\mathrm{V}_{\mathrm{x} 01}=2.77 \%, \\
\text { coefficient of variation }\end{array}$ \\
\hline $\begin{array}{c}\mathrm{R}=0.999 \\
\begin{array}{c}\text { Correlation coefficient, accepted } \\
\text { values } \mathrm{R} \geq 0.997\end{array} \\
\end{array}$ & \multicolumn{2}{|c|}{$\begin{array}{c}\bar{x}=0.256 \mu \mathrm{g} / \mathrm{L}, \sigma_{\text {blank }}=0.11 \mu \mathrm{g} / \mathrm{L} \\
\mathbf{L O D}=0.59 \mu \mathrm{g} / \mathrm{L}, \mathbf{L O Q}=1.34 \mu \mathrm{g} / \mathrm{L}\end{array}$} \\
\hline \multicolumn{3}{|c|}{ As, $\Lambda=188.979 \mathrm{~nm}$} \\
\hline $\begin{array}{c}y=-75.4+587.96 \cdot x \\
\text { linear equation }\end{array}$ & $\begin{array}{c}\mathrm{b}=587.96 \mu \mathrm{g}^{-1} \mathrm{~L} \\
\text { sensitivity, the slope of the calibration } \\
\text { curve }\end{array}$ & $\begin{array}{c}\mathrm{s}^{2}=0.12 \mathrm{E}+08, \\
\mathrm{~s}_{10}^{2}=0.61 \mathrm{E}+08, \mathrm{PG}=\mathrm{s}_{10}{ }_{10} / \mathrm{s}^{2}{ }_{1}= \\
5.06<\mathrm{F}_{9,9 ; 0,99}=5.35\end{array}$ \\
\hline $\begin{array}{l}\quad \mathrm{S}_{\mathrm{Y} 1}=90.15 \mu \mathrm{g} / \mathrm{L} \\
\text { residual standard deviation }\end{array}$ & $\begin{array}{c}\mathrm{S}_{\mathrm{x} 01}=0.15 \mu \mathrm{g} / \mathrm{L} \\
\text { method of standard deviation }\end{array}$ & $\begin{array}{c}\mathrm{V}_{\mathrm{x} 01}=1.39 \% \\
\text { coefficient of variation }\end{array}$ \\
\hline $\begin{array}{c}\mathrm{R}=0.9995 \\
\begin{array}{c}\text { Correlation coefficient, accepted } \\
\text { values } \mathrm{R} \geq 0.997\end{array}\end{array}$ & \multicolumn{2}{|c|}{$\begin{array}{c}\bar{x}=0.122 \mu \mathrm{g} / \mathrm{L}, \sigma_{\text {blank }}=0.03 \mu \mathrm{g} / \mathrm{L} \\
\mathbf{L O D}=0.21 \mu \mathrm{g} / \mathrm{L}, \mathbf{L O Q}=0.41 \mu \mathrm{g} / \mathrm{L}\end{array}$} \\
\hline \multicolumn{3}{|c|}{ Se, $\Lambda=197.197 \mathrm{~nm}$} \\
\hline $\begin{array}{c}y=-47.73+487.81 \cdot x \\
\text { linear equation }\end{array}$ & $\begin{array}{c}\mathrm{b}=487.81 \mu \mathrm{g}^{-1} \mathrm{~L} \\
\text { sensitivity, the slope of the calibration } \\
\text { curve }\end{array}$ & $\begin{array}{c}\mathrm{s}^{2}=4.27 \mathrm{E}+06, \\
\mathrm{~s}_{10}^{2}=18.26 \mathrm{E}+06, \mathrm{PG}=\mathrm{s}^{2}{ }_{10} / \mathrm{s}^{2}= \\
4.28<\mathrm{F}_{9,9 ; 0,99}=5.35\end{array}$ \\
\hline $\begin{array}{l}\quad \mathrm{S}_{\mathrm{Y} 1}=101.54 \mu \mathrm{g} / \mathrm{L} \\
\text { residual standard deviation }\end{array}$ & $\begin{array}{c}\mathrm{S}_{\mathrm{x} 01}=0.21 \mu \mathrm{g} / \mathrm{L} \\
\text { method of standard deviation }\end{array}$ & $\begin{array}{c}\mathrm{V}_{\mathrm{x} 01}=1.89 \% \\
\text { coefficient of variation }\end{array}$ \\
\hline $\begin{array}{c}\mathrm{R}=0.9995 \\
\begin{array}{c}\text { Correlation coefficient, accepted } \\
\text { values } \mathrm{R} \geq 0.997\end{array}\end{array}$ & \multicolumn{2}{|c|}{$\begin{array}{c}\bar{x}=0.095 \mu \mathrm{g} / \mathrm{L}, \sigma_{\text {blank }}=0.034 \mu \mathrm{g} / \mathrm{L} \\
\mathbf{L O D}=0.21 \mu \mathrm{g} / \mathrm{L}, \mathbf{L O Q}=0.43 \mu \mathrm{g} / \mathrm{L}\end{array}$} \\
\hline
\end{tabular}

In figures 1 and 2 the evolutions in time of peak height for As $(\Lambda=193.696 \mathrm{~nm})$ and Se are presented. The method measures the high of the peaks for each standard solution and processes the data in order to obtain a calibration curve.

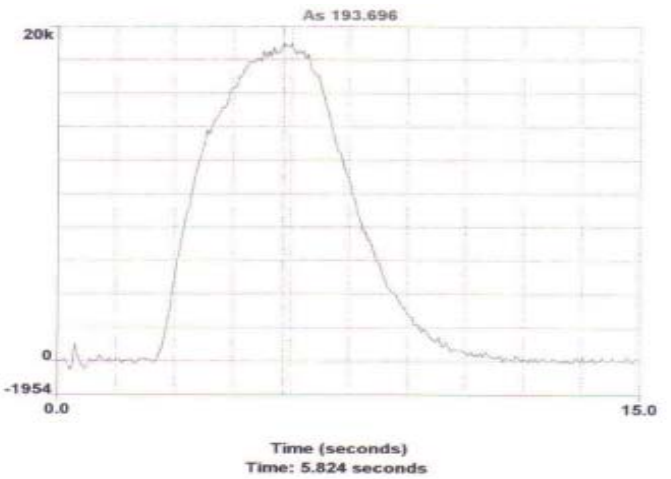

Fig. 1. Peak configuration for $\mathrm{As}(\Lambda=193.696 \mathrm{~nm})$

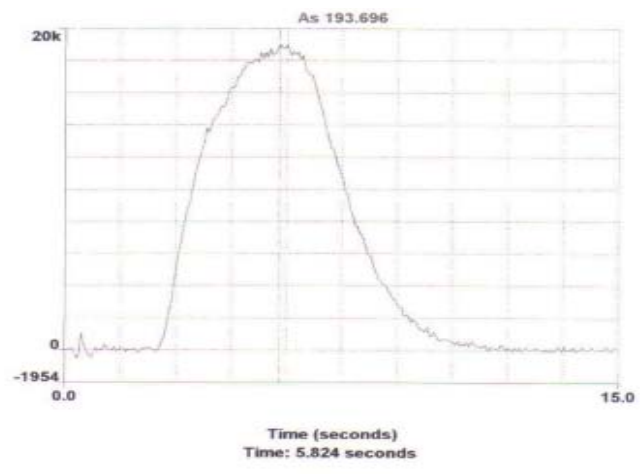

Fig. 2. Peak configuration for Se 
The Bias values are situated under the limit value for both elements and all wavelengths. The limit value is $2.82 \%$ for $99 \%$ confidence level and 9 freedom degrees. For $10 \mu \mathrm{g} / \mathrm{L}$ level of concentration, the recovery percentage must be situated within 60 and $115 \%$ range. In the Tables 6 and 7 all the obtained values of recovery percentage for different types of standard solutions respect needed requirement.

Table 6

Precision and bias data on SRM Merck

\begin{tabular}{|c|c|c|c|c|}
\hline \multirow{2}{*}{ Parameter } & \multicolumn{3}{|c|}{ ARSEN } & SELENIUM \\
\cline { 2 - 5 } & $\boldsymbol{\Lambda}=\mathbf{1 9 3 . 6 9 6} \mathbf{~ n m}$ & $\boldsymbol{\Lambda}=\mathbf{1 9 7 . 1 9 7} \mathbf{~ n m}$ & $\boldsymbol{\Lambda = 1 8 8 . 9 7 9} \mathbf{~ n m}$ & $\boldsymbol{\Lambda}=\mathbf{1 9 7 . 1 9 7} \mathbf{~ n m}$ \\
\hline RSD $_{\mathrm{r}}, \%$ & 1.87 & 2.03 & 1.02 & 1.40 \\
\hline Bias, \% & 1.99 & 0.99 & 2.50 & 1.59 \\
\hline
\end{tabular}

Recovery data on SRM Perkin Elmer

\begin{tabular}{|c|c|c|c|c|}
\hline \multirow[t]{2}{*}{ Parameter } & \multicolumn{3}{|c|}{ ARSEN } & \multirow{2}{*}{$\begin{array}{c}\text { SELENIUM } \\
\Lambda=197.197 \mathrm{~nm}\end{array}$} \\
\hline & $\Lambda=193.696 \mathrm{~nm}$ & $\Lambda=197.197 \mathrm{~nm}$ & $\Lambda=188.979 \mathrm{~nm}$ & \\
\hline \multicolumn{5}{|c|}{$5 \mu \mathrm{g} / \mathrm{L}$} \\
\hline $\bar{x}_{\mathrm{f}} \pm \mathrm{s}_{\mathrm{xf},} \mu \mathrm{g} / \mathrm{L}$ & $5.40 \pm 0.20$ & $5.38 \pm 0.23$ & $5.04 \pm 0.25$ & $4.54 \pm 0.19$ \\
\hline$\eta_{m} \pm s_{\eta}, \%$ & $103.74 \pm 3.92$ & $102.39 \pm 4.64$ & $98.43 \pm 5.07$ & $88.93 \pm 3.83$ \\
\hline \multicolumn{5}{|c|}{$15 \mu \mathrm{g} / \mathrm{L}$} \\
\hline $\bar{x}_{\mathrm{f}} \pm \mathrm{s}_{\mathrm{xf},} \mu \mathrm{g} / \mathrm{L}$ & $15.36 \pm 0.56$ & $15.33 \pm 0.51$ & $15.43 \pm 0.58$ & $14.52 \pm 0.12$ \\
\hline$\eta_{\mathrm{m}} \pm \mathrm{s}_{\eta}, \%$ & $100.98 \pm 3.74$ & $100.48 \pm 3.42$ & $102.04 \pm 3.85$ & $96.15 \pm 0.79$ \\
\hline \multicolumn{5}{|c|}{$20 \mu \mathrm{g} / \mathrm{L}$} \\
\hline $\bar{x}_{\mathrm{f}} \pm \mathrm{s}_{\mathrm{xf},} \mu \mathrm{g} / \mathrm{L}$ & $20.98 \pm 0.07$ & $21.14 \pm 0.11$ & $21.14 \pm 0.11$ & $20.02 \pm 0.23$ \\
\hline$\eta_{m} \pm s_{\eta}, \%$ & $102.16 \pm 1.96$ & $104.44 \pm 0.55$ & $105.09 \pm 0.53$ & $99.62 \pm 1.16$ \\
\hline
\end{tabular}

\section{Conclusions}

Single-laboratory validation is a valuable source of data usable to demonstrate the fitness-for-purpose of an analytical method. Also, the statistical interpretation of the experimental results prove that the proposed methods applied with FIAS-ICP-EOS equipment can be successfully used for the analytical control of the As and Se from drinking water, groundwater and surface water. Arsenic determination can be performed at three different wavelengths, $193.696 \mathrm{~nm}$, $197.197 \mathrm{~nm}$ and $188.979 \mathrm{~nm}$, the experimental data showed small differences for the obtained performance parameters. Selenium can be determined at $197.197 \mathrm{~nm}$.

\section{References}

[1]. Perkin Elmer, Inc., Flow Injection Mercury/Hydride Analyses. Recommended Analytical Condition and General Information, 2000, USA;

[2]. SR EN ISO 11969/2007: Water Quality. Determination of arsenic. Atomic absorption spectrometric method (hydride technique);

[3]. ISO 9965/1993: Water Quality. Determination of selenium. Atomic absorption spectrometric method (hydride technique);

[4]. World Health Organization, “Arsenic in drinking water", 2001, Geneva, Switzerland;

[5]. Gad, M.A.; Abd El-Twab, S.M.; Environmental Toxicology and Pharmacology 27, 2009; 7-16;

[6]. Wilber, C.G., “Toxicology of selenium”, Chemical Toxicology, 1980, 17, 171-230;

[7]. Niedzielski, P., Siepak, M., Siepak, J. and Przydryiek, J. Polish Journal of Environmental Studies. 2004;

[8]. ISO 15586 /2003: Determination of trace elements using atomic absorption spectrometry by graphite furnace;

[9]. Britta Planer-Friedrich, Corrine Lehr, Jorg Matschullat, Broder J. Merkel, Darrel Kirk Nordstrom and Mark W. Sandstrom; Geochimica et Cosmochimica Acta 70, 2006, 2480-2491;

[10]. SR EN ISO 11885/2008: Water quality. Determination of 33 elements by inductively coupled plasma atomic emission spectroscopy; 
[11]. Henk J van de Wiel, National Institute of Public Health and the Environmental (RIVM). Netherlands. Determination of elements by ICP-AES and ICP-MS, sept. 2003;

[12]. ISO 17294 - 2/2002 •- Water quality - Application for ICP-MS. Part 2: Determination of 62 elements;

[13]. EPA Method 6020A - 1998; Inductively coupled plasma - Mass spectrometry;

[14]. Toniolo, R.; Tubaro, F.; Bin, S.; Pizzariello, A.; Susmel, S.; Dossi, N. and Bontempelli G.; Talanta 78, 2009; 753-758;

[15]. Staniszewski, B. and Freimann, P.; Spectrochimica Acta Part B: Atomic Spectroscopy, Volume 63, Issue 11, 2008; 1333-1337;

[16]. Zhang, B.; Zhou, K.; Zhang, J.; Chen, Q.; Guorong Lin; Shang, H.; Qin, W.; Pinglan Li and Lin, T.; Food Chemistry, Volume 115, Issue 2, 2009, 727-734;

[17]. Hua, L.; Nishida, M.; Fujiwara, A.; Yashiki, M.; Nagao, M.and Namera, A.; Legal Medicine 11, 2008, 80-82;

[18]. Bauer,M.and Blodan, C.; Science of the Total Environment 354, 2006; 179-190;

[19]. CITAC/Eurachem Guide: Guide for Quality in Analytical Chemistry - An Aid to Accreditation, 2002;

[20]. I Taverniers, I.; De Loose, M. and Bockstaele, E. V. Trends in Analytical Chemistry, 23 (8), 535, 2004;

[21]. Hibbert, D. B., Quality Assurance for the Analytical Chemistry Laboratory, Oxford, University Press, 2007;

[22]. Tanase, I. Gh., Radu, G.L., Pana, A. and Buleandra, M., Analytical method validation, Printech Press, Bucharest, 2007. 